\title{
Evaluation of a New Hydrogen Generating System: Ni-Rich Magnesium Alloy Catalyzed by Platinum Wire in Sodium Chloride Solution
}

\author{
Chi-Yuan Cho, Kuo-Huang Wang and Jun-Yen Uan* \\ Department of Materials Engineering, National Chung Hsing University 250 Kuo-Kuang Rd., Taichung 402, Taiwan, R. O. China
}

Fuel cells are often seen as a long-term solution to environmental problems such as $\mathrm{CO}_{2}$ emission associated with transportation. To ensure long-term sustainability and the supply of fuel, new renewable of hydrogen $\left(\mathrm{H}_{2}\right)$ generator have to be introduced. In this study, Ni-rich AZ91D magnesium alloy ingot, which was considered as waste material, was used as a $\mathrm{H}_{2}$ generator in sodium chloride (NaCl) solution with catalyst. The chemical reaction $\mathrm{Mg}+\mathrm{H}_{2} \mathrm{O} \rightarrow \mathrm{H}_{2}+\mathrm{Mg}(\mathrm{OH})_{2}$ occurred in $\mathrm{NaCl}$ aqueous solution. The $\mathrm{H}_{2}$ evolution rate depended on the solution's temperature $\left(25\right.$ or $\left.70^{\circ} \mathrm{C}\right)$, length of catalyst $(0.9$ or $1.8 \mathrm{~m})$ and the concentration of $\mathrm{NaCl}$ solution $(5$ or 10 mass $\%)$. The $\mathrm{H}_{2}$ evolution rate increased with increasing the solution's temperature. The catalyst ( $\mathrm{Pt}$ wire) could significantly improve the $\mathrm{H}_{2}$ generation rate. In addition, the by-product of this method is $\mathrm{Mg}(\mathrm{OH})_{2}$, a non-toxic chemical compound which is usually used as flame retardant.

(Received June 17, 2005; Accepted September 6, 2005; Published December 15, 2005)

Keywords: hydrogen, corrosion, nickel, magnesium ingot, catalyst

\section{Introduction}

The challenge for automotive industry is to develop a clean and energy efficient vehicle to meet the need of $\mathrm{CO}_{2}$ reductions. Various options have been considered not only from the environmental aspect but also with respect to what they cost. Fuel cell is seen as a long-term solution to the environmental problems associated with transportation. ${ }^{1)}$ Currently, PEMFC (proton exchange membrane fuel cell) is regarded as the most suitable for fuel-cell-driven automobiles. Hydrogen $\left(\mathrm{H}_{2}\right)$ is a power source of the PEMFC. The $\mathrm{H}_{2}$ can be provided by several methods, ${ }^{2)}$ including steam reforming of hydrocarbons, electrolysis water and gasification of heavy oil, coal or biomass. ${ }^{3)}$ However, $\mathrm{H}_{2}$ is only an energy carrier, not a source of energy such as oil, gas or natural gas, etc. It must be manufactured using energy from other sources. ${ }^{4)}$ For this reason, hydrogen production actually consumes more energy than that contained in the resulting hydrogen itself. ${ }^{5)}$ To ensure long-term sustainability and the supply of fuel, a new renewable of $\mathrm{H}_{2}$ generator have to be introduced. Amendola et al. ${ }^{6,7)}$ have explored a new method to generate hydrogen gas from sodium borohydride $\left(\mathrm{NaBH}_{4}\right)$, sodium hydroxide $(\mathrm{NaOH})$ and $\mathrm{H}_{2} \mathrm{O}$ mixed solution with $\mathrm{Ru}-$ based catalyst. When $\mathrm{NaBH}_{4}$ aqueous solution contacted with the catalyst, it spontaneously hydrolyzes to form $\mathrm{H}_{2}$ gas and sodium borate $\left(\mathrm{NaBO}_{2}\right)$,, 7$)$ Such investigations are significant for producing high quality hydrogen without polluting emissions. However, a disadvantage is that $\mathrm{NaBH}_{4}$ is made from borax, a material that is found in substantial natural reserves globally. Currently, the production cost of $\mathrm{NaBH}_{4}$ is still high, which is about 80 US dollars per kilogram. ${ }^{7)}$

\section{Background of $\mathbf{H}_{2}$ Generation from Ni-rich AZ91D Magnesium Ingot}

Magnesium alloy was considered as an environment-

*Corresponding author, E-mail: jyuan@dragon.nchu.edu.tw friendly material; one of the reasons is that the alloy is recyclable. In ASTM B93 standard for magnesium alloy ingot, the maximum $\mathrm{Ni}$ content should be less than $10 \mathrm{ppm}$. It is because the $\mathrm{Ni}$ element causes the formation of $\mathrm{Mg}-\mathrm{Ni}$ compound in $\mathrm{Mg}$ matrix, leading to an extremely deleterious effect on corrosion resistance of magnesium alloys. ${ }^{8)}$ Once the Ni content in recycled ingot exceeds this limit, the ingot is usually discarded and considered as a waste. Thus, the Nirich ingot is inexpensive. The handling charge for magnesium scraps in recycling casthouse is approximately 1.1 US dollars per kilogram. ${ }^{9)}$

Electroless $\mathrm{Ni}$ plating is a common process for surface coating of AZ91D magnesium product. ${ }^{10,11)}$ For the recycling of the magnesium scraps, it is difficult to remove $\mathrm{Ni}$ from the molten magnesium due to strong affinities between $\mathrm{Ni}$ and Mg. ${ }^{12)}$ In present work, Ni-rich AZ91D magnesium ingot, which was considered as waste material, was used as a $\mathrm{H}_{2}$ generator. Previous studies ${ }^{13,14)}$ have suggested that the overall reaction for the corrosion of magnesium is:

$$
\mathrm{Mg}+2 \mathrm{H}_{2} \mathrm{O}=\mathrm{H}_{2}+\mathrm{Mg}(\mathrm{OH})_{2}
$$

To promote $\mathrm{H}_{2}$ generation rate, the overall reaction in $\mathrm{NaCl}$ solution with catalyst for the $\mathrm{H}_{2}$ production may be expressed below:

$$
\mathrm{Mg}(\mathrm{s})+2 \mathrm{H}_{2} \mathrm{O}(\mathrm{l}) \stackrel{\mathrm{NaCl} \text { solution }}{\underset{\text { Catalyst }}{\longrightarrow}} \mathrm{H}_{2}(\mathrm{~g})+\mathrm{Mg}(\mathrm{OH})_{2}(\mathrm{~s})
$$

In addition, the by-product, $\mathrm{Mg}(\mathrm{OH})_{2}$, is a non-toxic chemical compound which is usually used as flame retardant. ${ }^{15)}$ Song ${ }^{16)}$ and Lunder ${ }^{17)}$ reported that a more direct way to determine corrosion rate is to measure the total amount of $\mathrm{H}_{2}$ evolution from the magnesium specimen. Experimental results showed that the total amount of $\mathrm{H}_{2}$ was increased with increasing the corrosion rate. ${ }^{16,17)}$ Figure 1 depicts a stack of Ni-rich AZ91 ingots and a qualified AZ91 ingot. The Ni-rich AZ91 ingot, due to careless scrap classification, was oxidized with dark surface. Figure 2 shows the curves of electrochemical polarization of Ni-rich and qualified AZ91 samples. As elucidated in Fig. 2, the Ni-rich AZ91 sample 


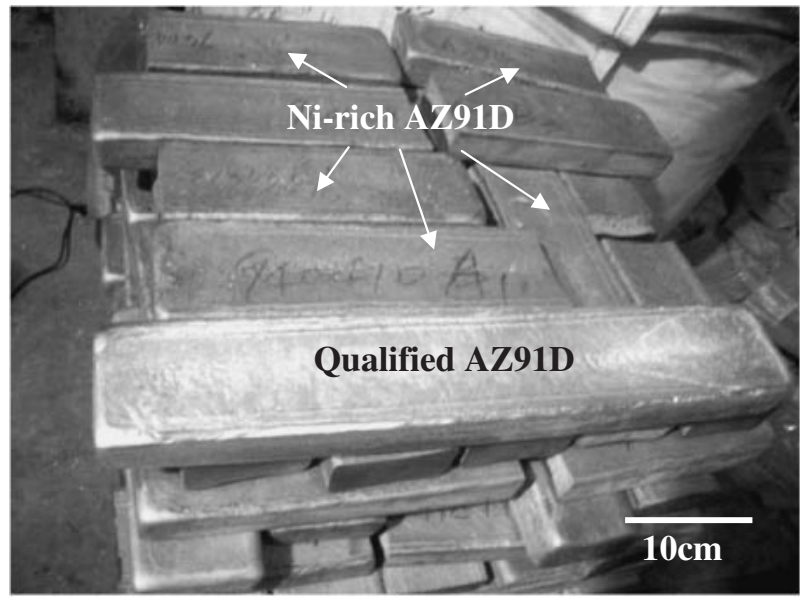

Fig. 1 The recycled Ni-rich AZ91D ingots and a qualified AZ91D ingot.

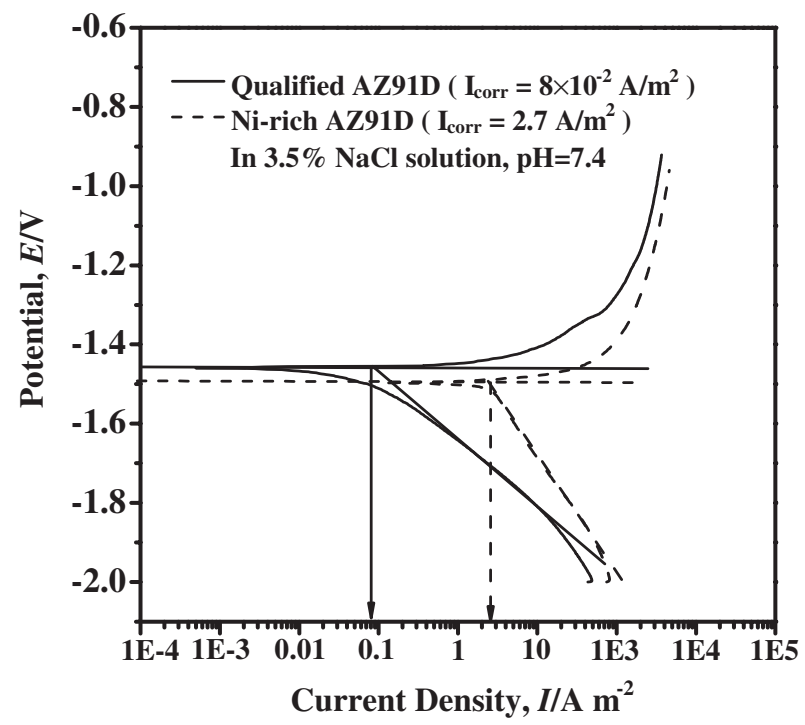

Fig. 2 Polarization curves of the qualified AZ91D and the Ni-rich AZ91D.

had corrosion current density $\left(\mathrm{I}_{\text {corr }}\right) \sim 2.7 \mathrm{~A} / \mathrm{m}^{2}$, which is about 2 order higher than the qualified ones $\left(\sim 8 \times 10^{-2} \mathrm{~A} /\right.$ $\left.\mathrm{m}^{2}\right)$. The experimental result revealed that the Ni-rich AZ91D magnesium ingots had inferior corrosion resistance.

This article addressed the hydrogen generation from the Ni-rich AZ91D magnesium ingot in $\mathrm{NaCl}$ solution with catalyst. The solution's temperature, length of catalyst and the concentration of $\mathrm{NaCl}$ solution were studied to investigate the $\mathrm{H}_{2}$ generation rate. The weight loss of Ni-rich AZ91 sample was examined. The findings in this report not only suggest a method to generate hydrogen but also promote the recycling of the used magnesium products that were plated with $\mathrm{Ni}$.

\section{Experimental Procedures}

Table 1 presents the chemical compositions of the Ni-rich AZ91D magnesium specimen. The Ni content in the specimen was 10 times greater than that in a qualified AZ91D magnesium ingot. The dimension of the Ni-rich AZ91D sample was $3 \mathrm{~mm}$ in thickness, 20 and $40 \mathrm{~mm}$ for the width
Table 1 Chemical compositions of the Ni-rich AZ91D magnesium alloy.

\begin{tabular}{ccccccccc}
\hline Composition & $\mathrm{Al}$ & $\mathrm{Zn}$ & $\mathrm{Mn}$ & $\mathrm{Si}$ & $\mathrm{Cu}$ & $\mathrm{Fe}$ & $\mathrm{Ni}$ & $\mathrm{Mg}$ \\
\hline mass $\%$ & 9.09 & 0.63 & 0.24 & 0.02 & 0.002 & 0.002 & 0.0148 & $\mathrm{Bal}$ \\
\hline
\end{tabular}

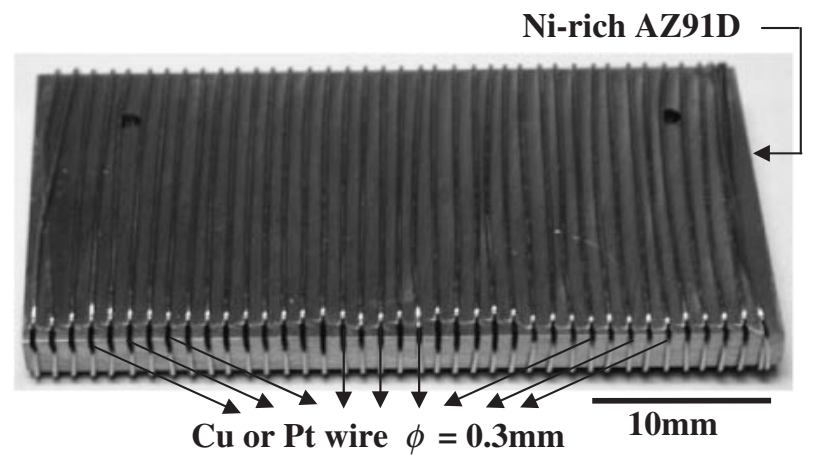

Fig. 3 The Ni-rich AZ91D sample and the catalyst (Cu or Pt wire).

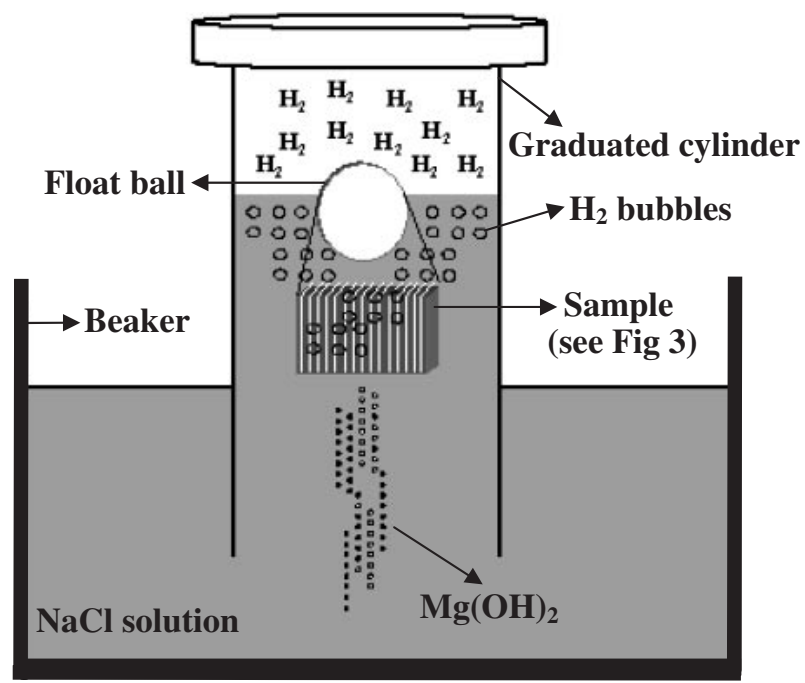

Fig. 4 The schematic illustration of hydrogen generation set-up.

and length. The samples were cleaned with ethyl alcohol, and then dried in furnace $\left(70^{\circ} \mathrm{C}\right)$. Platinum $(\mathrm{Pt})$ and copper $(\mathrm{Cu})$ were used as catalyst. The Pt wire were 0.9 or $1.8 \mathrm{~m}$ in length and both with diameter $0.3 \mathrm{~mm}$. The $\mathrm{Cu}$ wire was $0.9 \mathrm{~mm}$ in length and $0.3 \mathrm{~mm}$ in diameter. Figure 3 shows the catalyst (Pt or $\mathrm{Cu}$ wire) was being fastened to the sample. The sample was dipped in $\mathrm{NaCl}$ aqueous solution for $\mathrm{H}_{2}$ generation. The concentration of the $\mathrm{NaCl}$ solution was 5 or 10 mass\%. As the schematic illustration indicated in Fig. 4, an inverted graduated cylinder filled with the $\mathrm{NaCl}$ solution was immersed in a beaker containing the solution. The sample with catalyst wire fixed with a float ball was then put into the cylinder. The liquid in cylinder would be drained out, owing to the hydrogen generation (Figs. 4 and 5). In addition, ultrasonic vibration equipment was applied to study the vibration effect on $\mathrm{H}_{2}$ generation rate. The weight loss of the Ni-rich AZ91D specimen after $\mathrm{H}_{2}$ generation experiment was measured. To obtain the weight loss data, corrosion product on the sample after $\mathrm{H}_{2}$ generation was cleaned using the 


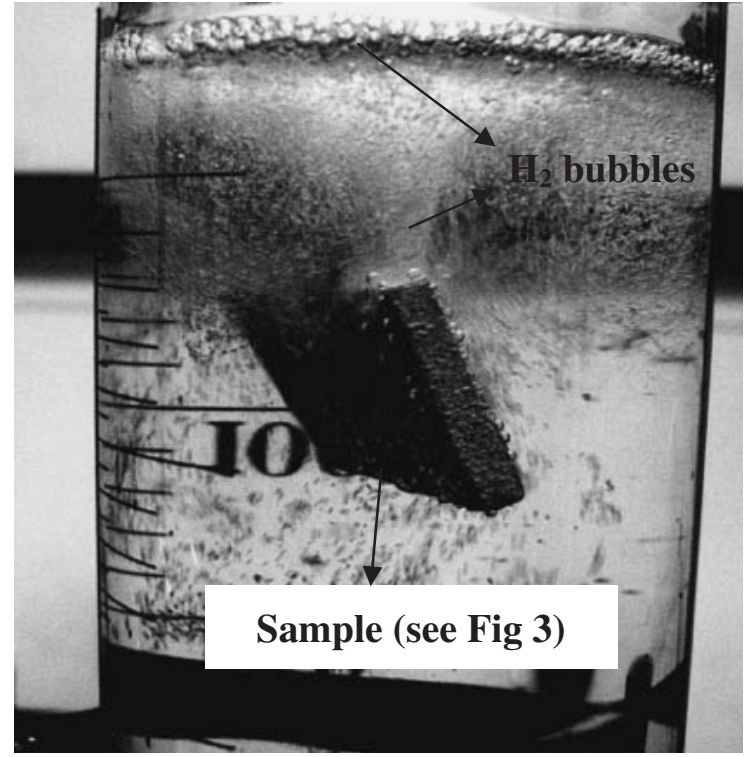

Fig. 5 The Ni-rich AZ91D sample with catalyst, generating $\mathrm{H}_{2}$ in the inverted graduated cylinder.

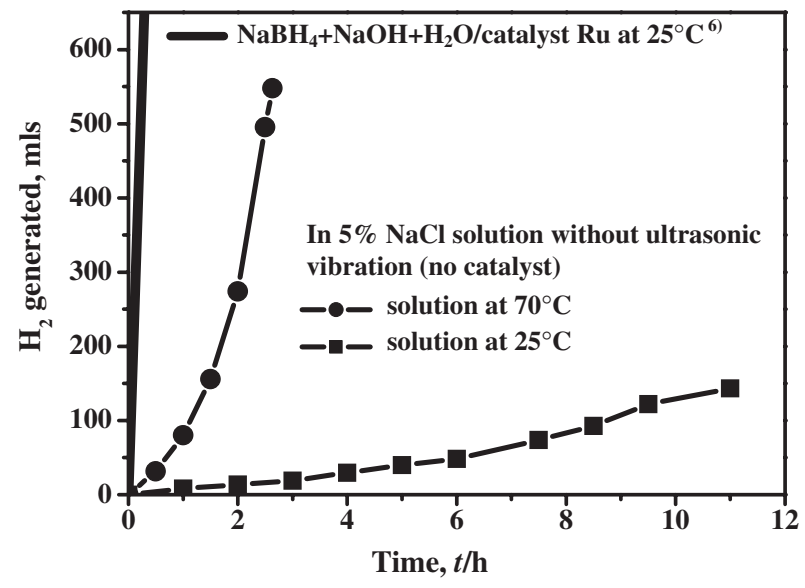

Fig. $6 \mathrm{H}_{2}$ generated from the Ni-rich AZ91D sample vs. time in 5 mass $\% \mathrm{NaCl}$ solution in the absence of catalyst. Hereafter, the plot of $\mathrm{NaBH}_{4}+\mathrm{NaOH}+\mathrm{H}_{2} \mathrm{O} /$ catalyst $\mathrm{Ru}$ at $25^{\circ} \mathrm{C}$ was redrew according to the data of a previous study. ${ }^{\text {) }}$

procedures as described elsewhere. ${ }^{18)}$ An X-ray diffractometer using $\mathrm{Cu} \mathrm{K}_{\alpha}$ radiation operated at $40 \mathrm{KV}$ was employed to examine the chemical reaction product after the reaction for $\mathrm{H}_{2}$ generation. An X-ray scanning speed of 1 degree/ minute was used.

\section{Results and Discussion}

Figure 6 shows the $\mathrm{H}_{2}$ volume generated from the Ni-rich AZ91D sample in 5 mass $\% \mathrm{NaCl}$ aqueous solution in the absence of catalysts. As elucidated in Fig. 6, the temperature of the $\mathrm{NaCl}$ solution was able to affect the $\mathrm{H}_{2}$ generation rate. The rate of the $70^{\circ} \mathrm{C}$ experiment was about three times higher than that of the sample in the $25^{\circ} \mathrm{C}$ solution. The weight loss of the Ni-rich AZ91D sample after the $\mathrm{H}_{2}$ generation experiments was about 0.22 and $0.47 \mathrm{~g}$ for the 70 and $25^{\circ} \mathrm{C}$ experiments, respectively. The data of a previous study ${ }^{6}$

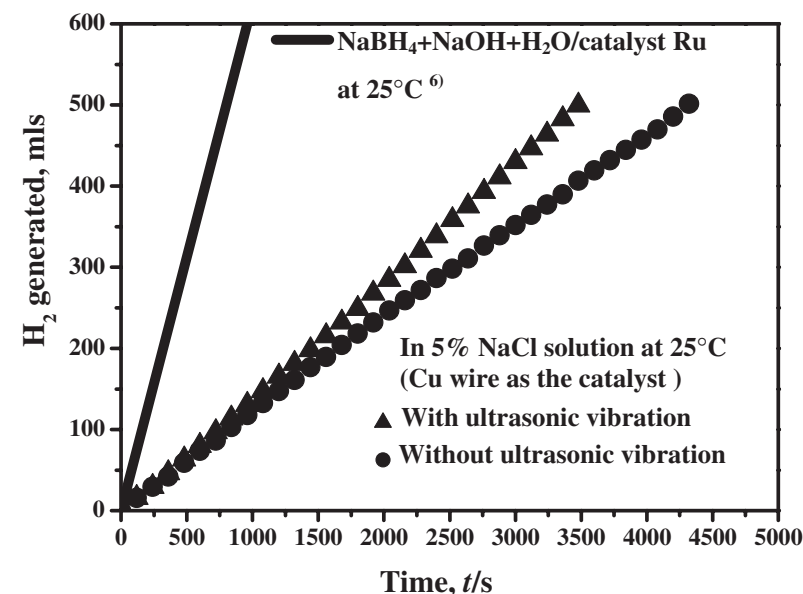

Fig. $7 \mathrm{H}_{2}$ volume generated from the Ni-rich AZ91D sample catalyzed by $\mathrm{Cu}$ wire vs. time in 5 mass $\% \mathrm{NaCl}$ solution at $25^{\circ} \mathrm{C}$.

about $\mathrm{H}_{2}$ generation from the aqueous borohydride $\left(\mathrm{NaBH}_{4}\right)$ solution and $\mathrm{Ru}$ catalyst were also plotted in Fig. 6. The $\mathrm{H}_{2}$ generation rate of present study was lower, as compared to the previous result.

The data of $\mathrm{H}_{2}$ volume generated from the Ni-rich AZ91D in the presence of $\mathrm{Cu}$ catalyst were depicted in Fig. 7. For exploring the effect of ultrasonic vibration on the $\mathrm{H}_{2}$ production rate, the $\mathrm{H}_{2}$ generation set-up (see Fig. 4) was placed into an ultrasonic vibration cleaner. The data points shown in Fig. 7 elucidated that ultrasonic vibration could effectively promote the $\mathrm{H}_{2}$ generation rate. The $\mathrm{H}_{2}$ generation rate from the $\mathrm{Ni}$-rich $\mathrm{AZ91D}$ catalyzed by $\mathrm{Cu}$ wire was much higher than that from the same alloy without catalyst ( $c f$., data in Fig. 6). Nevertheless, it is only about one half of the $\mathrm{H}_{2}$ generation rate by $\mathrm{NaBH}_{4}$ solution/Ru catalyst. ${ }^{6)}$ Figure 8 presents the significant improvement of the $\mathrm{H}_{2}$ production from the Ni-rich AZ91D sample catalyzed by Pt wire. The data points in Fig. 8 were obtained from the

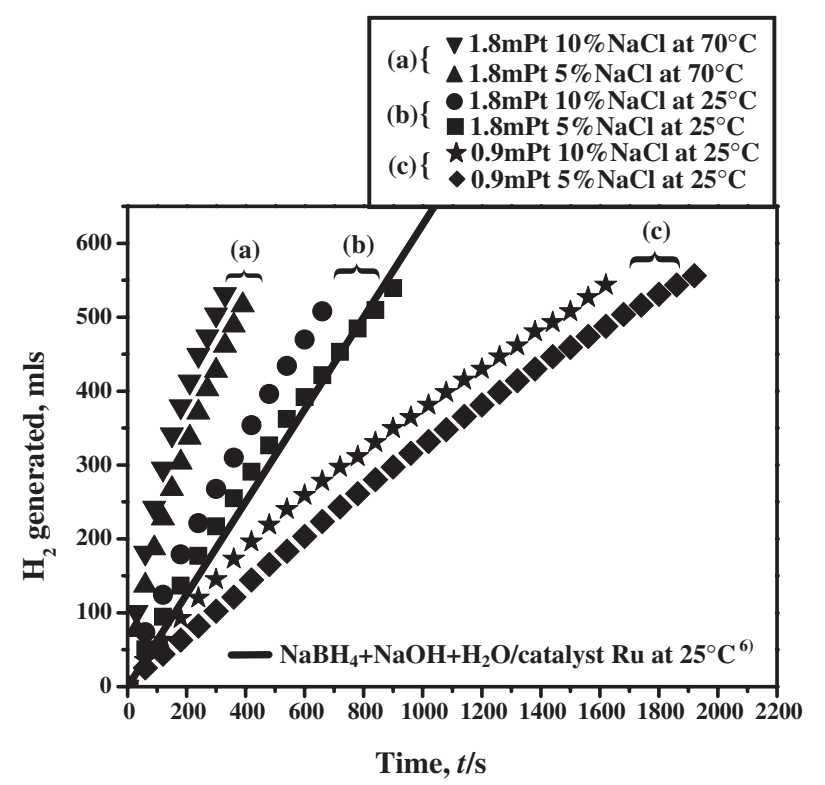

Fig. $8 \mathrm{H}_{2}$ from the Ni-rich AZ91D sample catalyzed by Pt wire $v s$. time in 5 and 10 mass $\% \mathrm{NaCl}$ solutions. 
experiments under ultrasonic vibration. As indicated in this figure, there are three groups of data sets: (a), (b) and (c). The data set "(a)" presented the $\mathrm{H}_{2}$ generation rate of the AZ91D sample catalyzed by 1.8 meters Pt wire (e.g., see the sample in Fig. 3) in the solution of $70^{\circ} \mathrm{C}$. The sample in $10 \% \mathrm{NaCl}$ solution generated $\mathrm{H}_{2}$ in a higher rate than the sample in the $5 \%$ solution did. Similar results were obtained for the samples tested in the $\mathrm{NaCl}$ solution at $25^{\circ} \mathrm{C}$ (see the data set "(b)" in Fig. 8). The $\mathrm{H}_{2}$ generation rate was substantially improved by using $\mathrm{Pt}$ wire as the catalyst for the reaction: $\mathrm{Mg}_{(\mathrm{s})}+2 \mathrm{H}_{2} \mathrm{O}_{(\mathrm{l})} \rightarrow \mathrm{H}_{2(\mathrm{~g})}+\mathrm{Mg}(\mathrm{OH})_{2(\mathrm{~s})}$. For the $\mathrm{H}_{2}$ volume created from zero to $\sim 550 \mathrm{~mL}$, the data set "(a)" and "(b)" showed a good efficiency that spent no more than $800 \mathrm{~s}$ to achieve. The $\mathrm{H}_{2}$ generation rate is as good as the result of previous study via $\mathrm{NaBH}_{4}$ solution/Ru catalyst at $25^{\circ} \mathrm{C}$. ${ }^{6}$ ) The weight losses of the samples for the $\mathrm{H}_{2}$ generation in Fig. 8 were in the range between 0.29 and $0.62 \mathrm{~g}$.

One of the by-products of the catalyzed reaction is magnesium hydroxide $\left(\mathrm{Mg}(\mathrm{OH})_{2}\right)$, which is non-toxic, noncorrosive $^{19)}$ and is one of the most widely used metal hydroxide flame retardant additives for polymers. ${ }^{20)}$ As the AZ91D sample being generating $\mathrm{H}_{2}$ in $\mathrm{NaCl}$ solution, some solid compound was being condensed in beaker, as schematically shown in Fig. 4. The compounds were collected and rinsed in distilled water to dilute the $\mathrm{NaCl}$ concentration. Figure 9 is the $\mathrm{X}$-ray diffraction pattern of the compound, showing that the compound is $\mathrm{Mg}(\mathrm{OH})_{2}$. Another byproduct, which was being synchronically mixed in the $\mathrm{H}_{2}$ gas stream during the hydrogen generation, is water vapor. Prehumidified $\mathrm{H}_{2}$ is needed in proton exchange membrane fuel cells, ${ }^{6}$ ) since the electric conductivity depends significantly on the water content in the fuel cell, especially in the membrane. ${ }^{21,22)}$ As indicated in Fig. 10, several ice cubes were continually put on the top of the cylinder that containing the $\mathrm{H}_{2}$ gas produced by present method at $25^{\circ} \mathrm{C}$. The condensed water drop (as shown in Fig. 10) was not seen until three hours were spent in keeping the container's top cooled down. The experimental result suggested that the total gas volume not only contained $\mathrm{H}_{2}$ but also had a few water vapor. However, the present report did not examine the volume fraction of water vapor existing in the $\mathrm{H}_{2}$ gas stream.

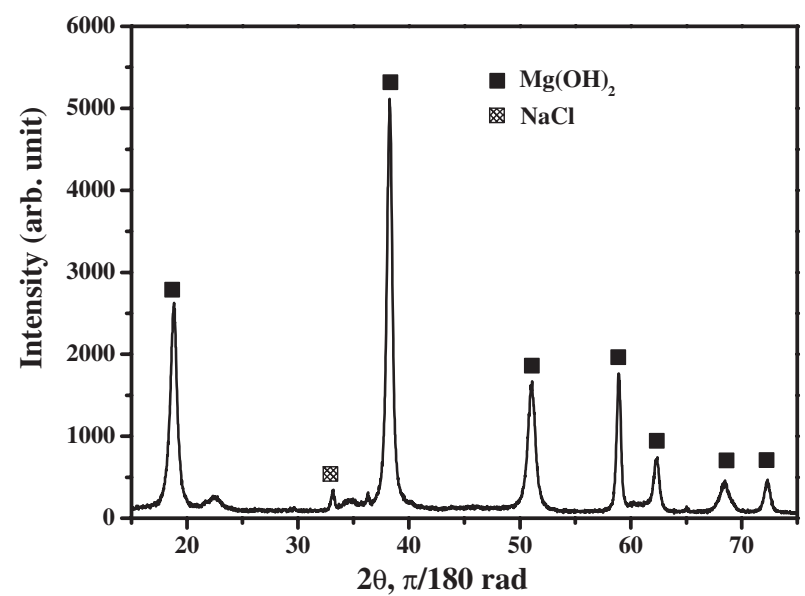

Fig. 9 X-ray diffraction pattern of the by-product compound after $\mathrm{H}_{2}$ generation, showing that the compound is magnesium hydroxide $\left(\mathrm{Mg}(\mathrm{OH})_{2}\right)$.

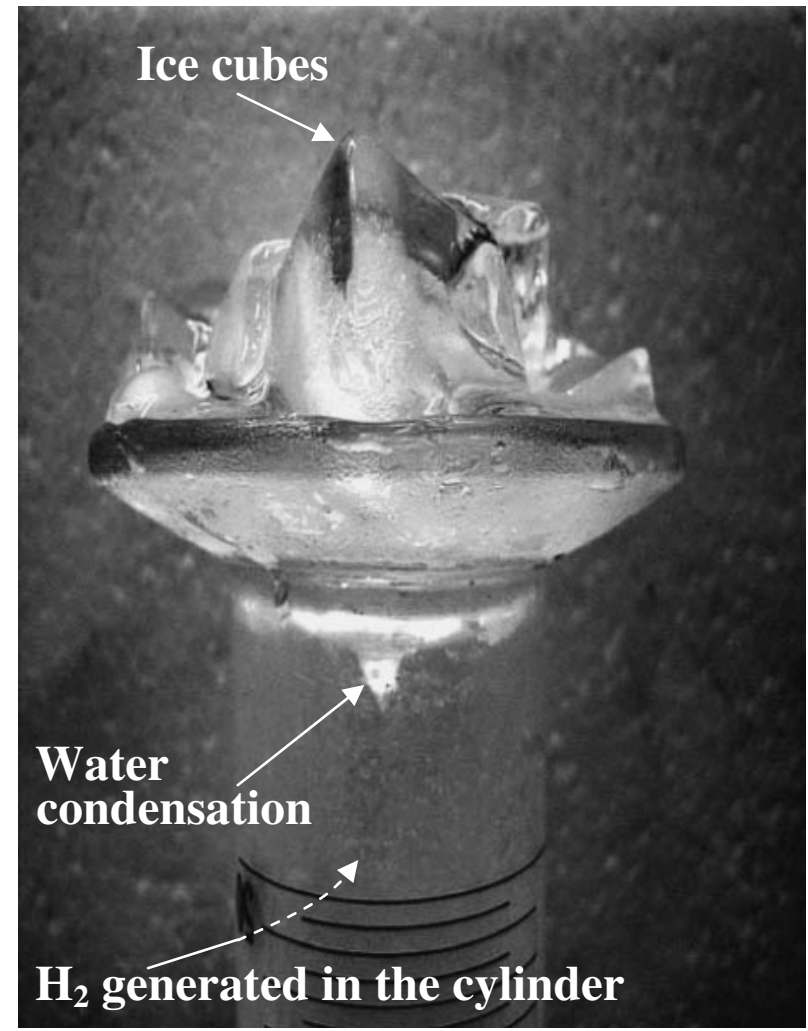

Fig. 10 A water drop condensed by ice cubes, showing the existence of water vapor in the generated hydrogen volume.

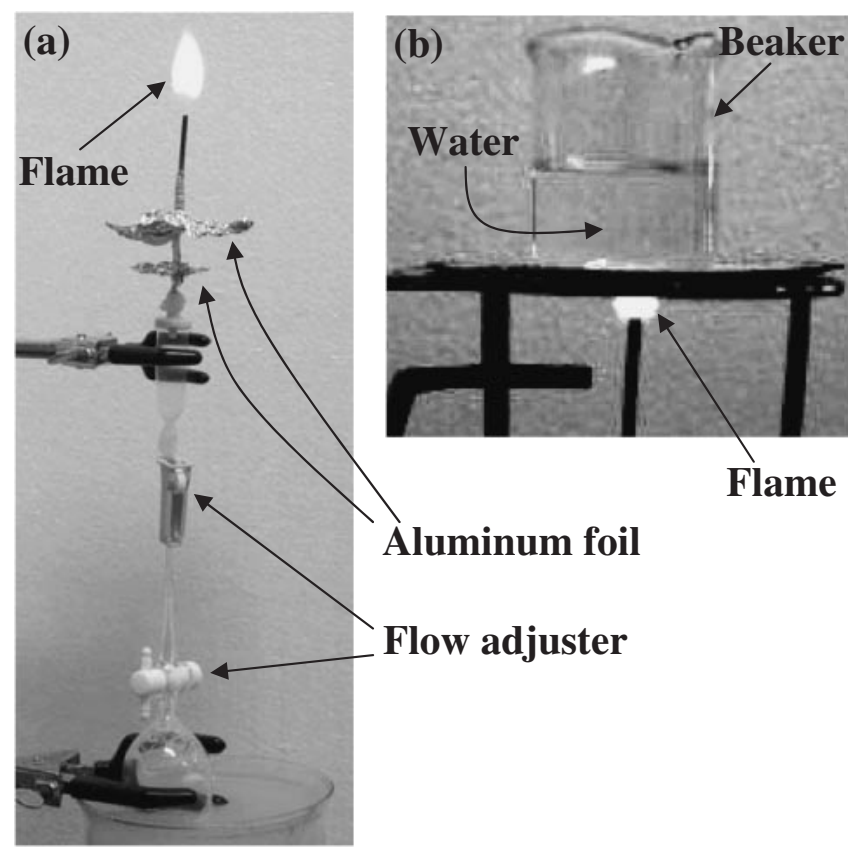

Fig. 11 (a) and (b), a set-up to view the hydrogen flame. The $\mathrm{H}_{2}$ was generated in the $\mathrm{NaCl}$ solution at $25^{\circ} \mathrm{C}$.

It was believed that the gas volume produced at $70^{\circ} \mathrm{C}$ (see Figs. 6 and 8) contained more water vapor than that at $25^{\circ} \mathrm{C}$.

Figure 11 shows a set-up to view the hydrogen flame, and to see how long the flame could last. Hydrogen ignited and produced a bark-like noise, when mixed with the oxygen of the air. ${ }^{23)}$ This reaction is the positive test for hydrogen gas. ${ }^{23)}$ 
The hydrogen was coming from the Ni-rich AZ91 sample catalyzed by $\mathrm{Pt}$ wire at the solution temperature of $25^{\circ} \mathrm{C}$. Figures 11(a) and (b) reveal the hydrogen flame, which could keep burning for about $1 \mathrm{~h}$.

\section{Conclusion}

(1) The corrosion rate of the Ni-rich AZ91D ingot can be greatly bigger than that of the qualified AZ91D alloy. The corrosion current density of the former material is $2.7 \mathrm{~A} / \mathrm{m}^{2}$, which is two order higher than that of the latter material.

(2) Ni-rich AZ91D magnesium ingot can be used to generate hydrogen $\left(\mathrm{H}_{2}\right)$ in $\mathrm{NaCl}$ aqueous solution. The $\mathrm{NaCl}$ concentration in the solution evidently affects the hydrogen generation rate. More $\mathrm{NaCl}$ dissolved in the solution resulted in a superior rate of $\mathrm{H}_{2}$ generation. The rate of $\mathrm{H}_{2}$ generation was experimentally confirmed to be increased by ultrasonic vibration.

(3) Platinum wire can be employed as the catalyst for the reaction: $\mathrm{Mg}_{(\mathrm{s})}+2 \mathrm{H}_{2} \mathrm{O}_{(\mathrm{l})} \rightarrow \mathrm{H}_{2(\mathrm{~g})}+\mathrm{Mg}(\mathrm{OH})_{2(\mathrm{~s})}$. Given the sample size $\left(3 \times 20 \times 40 \mathrm{~mm}^{3}\right)$ and the Pt wire used herein, $\sim 550 \mathrm{~mL}$ of $\mathrm{H}_{2}$ was produced in 10 minutes after the above chemical reaction at $25^{\circ} \mathrm{C}$.

\section{Acknowledgment}

The authors thank Pinda Tech Co. Ltd., Taoyuan, Taiwan for providing the AZ91D magnesium alloy ingots used in this study. This work was financially supported by the National Science Council of Taiwan for which we are grateful (Contract No. NSC 93-2216-E-005-012).

\section{REFERENCES}

1) P. Ekdunge and M. Råberg: Int. J. Hydrogen Energy 23 (1998) 381385.
2) J. M. Ogden, M. M. Steinbugler and T. G. Kreutz: J. Power Sources 79 (1999) 143-168.

3) G. W. Huber, J. W. Shabaker and J. A. Dumesic: Science 300 (2003) 2075-2077.

4) M. L. Wald: Scientific American 290 (2004) 66-73.

5) S. Ashley: Scientific American 292 (2005) 50-57.

6) S. C. Amendola, S. L. Sharp-Goldman, M. S. Janjua, M. T. Kelly, P. J. Petillo and M. Binder: J. Power Sources 85 (2000) 186-189.

7) S. C. Amendola, S. L. Sharp-Goldman, M. S. Janjua, N. C. Spencer, M. T. Kelly, P. J. Petillo and M. Binder: Int. J. Hydrogen Energy 25 (2000) 969-975.

8) J. D. Hanawalt, C. E. Nelson and J. A. Pelubet: Trans. AIME 147 (1942) 273-299.

9) K. W. Chang: Production Manager, Pinda Tech Co. Ltd., Taoyuan, Taiwan, private communication, 2005.

10) Y. Xiang, W. Hu, X. Liu, C. Zhao and W. Ding: Trans. Inst. Metal. Finish. 79 (2001) 27-29.

11) A. K. Sharma, M. R. Sureah, H. Bhojraj, H. Narayanamurthy and R. P. Sahu: Met. Finish. 96 (1998) 10-18.

12) M. M. Avedesian and H. Baker (Eds.): ASM Specialty Handbook: Magnesium and Magnesium Alloys, (ASM International, Materials Park, OH, 1999) pp. 194-196.

13) G. L. Marker and J. Kruger: J. Electrochem. Soc. 137 (1990) 414-421.

14) M. R. Bothwell and H. P. Godard: The Corrosion of Light Metals, (John \& Son, NY, 1967) p. 257.

15) M. Shigeo, I. Takeshi and A. Hitoshi: J. Appl. Polym. Sci. 25 (1980) $415-425$.

16) G. Song, A. Atrens and D. StJohn: Magnesium Technology 2001, ed. by J. N. Hryn, (Proceeding of the symposium held during TMS Annual Meeting, New Orleans, LA, TMS, 2001) pp. 255-262.

17) O. Lunder: Corros. Rev. 15 (1997) 439-469.

18) B. L. Yu and J. Y. Uan: Metall. Mater. Trans. A 36A (2005) 22452252.

19) P. R. Hornsby and C. L. Watson: Plast. Rubber Process. Appl. 6 (1986) 169-175.

20) M. Sain, S. H. Park, F. Suhara and S. Law: Polym. Degrad. Stabil. 83 (2004) 363-367.

21) P. Costamagna and S. Srinivasan: J. Power Sources 102 (2001) 253269.

22) F. Chen, Y. G. Su, C. Y. Soong, W. M. Yan and H. S. Chu: J. Electroanal. Chem. 566 (2004) 85-93.

23) L. R. Summerlin, C. L. Borgford and J. B. Ealy: Chemical Demonstrations: A Sourcebook for Teachers, (American Chemical Society, Washington, DC, 1988) p. 51. 